\title{
A "Pedra do Reino" reconquista o Brasil após um quarto de século
}

\author{
Sérgio Sálvia Coelho
}

I

á mais de vinte anos atrás, em uma apresentação especial para a família de Suassuna da adaptação de seu romance $A$ Pedra do Reino por Antunes Filho, um figurante errou uma curva durante uma "cavalgada" e fez desabar uma das pedras, feitas de um amontoado de cadeiras. O fato do projeto então não ter sido aprovado foi tema de devaneios culpados para ele desde então. Que esse pobre ator tenha se tornado hoje o crítico destas linhas é um bom exemplo da ironia do destino, e, declarada a parcialidade do seu ponto de vista, um convite a que o leitor veja a crítica além do relato de uma amizade conturbada.

São raros os exemplos em teatro de uma montagem que tenha empregado um quarto de século para sua concepção. Mais precioso, portanto, é o fato de chegar em um resultado tão límpido, despojado, essencial. Para quem participou dos primeiros esboços, é possível afirmar que pouco da estrutura original, arquitetada com paixão por, entre outros, Cecília Homem de Mello, foi abandonada.

Ainda se trata do depoimento de Quaderna, uma espécie de Dom Quixote do terceiro mundo, réu de um processo político do qual se esquiva com a verve de um cordelista. Em contraste com a trama simples, os momentos de delírio estratégico enchem o palco com o minimalismo barroco do melhor Antunes.

Depois de anos pontificando sobre tragédia grega, na aplicação de um método de ator cuja sobriedade não raro soava impostada, Antunes volta para casa. Que acorram os fãs fiéis: estão em cena o coro carnavalesco de $\mathrm{Ma}$ cunaíma, a fila de cadeiras de Toda Nudez Será Castigada e o narrador-figurante de Romeu e Julieta. Mas essa volta ao terreno seguro não significa uma capitulação.

Mudou Antunes e mudou o Brasil. Tudo o que havia de sentencioso, quase lacrimoso, da primeira versão da "Pedra" caiu por si só, assim como o triunfalismo heróico se desmascarou nas sessões das CPIs. Não se trata aqui de propor Quaderna-Suassuna como herói da raça, um novo Conselheiro a ser seguido; nem do antiherói auto-indulgente Macunaíma. Palhaço que não perde a majestade, Quaderna refaz seu reino pela força da ingenuidade, sua arte armorial chega ao arquétipo pela mão do velho faceta do pastoril.

E é aí que o jovem ator Lee Thalor se torna a pessoa certa na hora certa. Antunes, que trabalha com atores maleáveis em coros camaleões, necessita igualmente de um protagonista artilheiro. Thalor ocupa com firmeza um cargo

Sérgio Sálvia Coelho é pesquisador e crítico de teatro da Folha de S. Paulo. 
de responsabilidade, de brilhantes antecessores, como Cacá Carvalho e Marcos Oliveira. Seu rosto de profeta mineiro, de meio sorriso que camufla a inteligência, sua precisão de movimentos, nas rotinas tradicionais do palhaço, faz, junto à vibrante cenografia de Juliana Fernandes, um universo no qual a trágica máquina do destino grego dá lugar à hábil mecânica da geringonça, no Brasil de Mestre Vitalino.
Assumindo-se enquanto fraude hilária, para melhor expor a sua dor, Quaderna vem nos restituir auto-estima depois da dura prova das CPIs. Contra o charlatanismo das mea-culpas pela metade, que a imaginação venha ao poder: a República não é legítima. Entre a Quaresma e o Carnaval, o Brasil está presente como há tempos não se via nos palcos do $\mathrm{CPT}$. Bem vindo de volta, Mestre Antunes. 